\title{
Impact of socioeconomic status on patient experience: A cross sectional exit survey of Nigeria Teaching Hospitals.
}

Henry Egi Aloh ( $\nabla$ henryealoh@gmail.com )

Health Economics and Policy Research Unit, Department of Health Services, Alex Ekweume Federal University Ndufu-Alike Ikwo, Ebonyi State, Nigeria https://orcid.org/0000-0001-9263-2547

\section{Obinna E. Onwujekwe}

University of Nigeria Faculty of Health Sciences and Technology

\section{Obianuju G. Aloh}

Federal University Ndufu Alike

\section{ljeoma L. Okoronkwo}

University of Nigeria Faculty of Health Sciences and Technology

\section{Chijioke Joel Nweke}

Federal University Ndufu Alike

\section{Research article}

Keywords: Quality of care, Patient Experience, Socioeconomic Status, Hospitals, Nigeria

Posted Date: December 17th, 2019

DOI: https://doi.org/10.21203/rs.2.19043/v1

License: (a) (i) This work is licensed under a Creative Commons Attribution 4.0 International License. Read Full License

Version of Record: A version of this preprint was published at BMC Health Services Research on May 26th, 2020. See the published version at https://doi.org/10.1186/s12913-020-05332-0. 


\section{Abstract}

Background: To determine how socioeconomic factors, such as level of education and employment status, affect quality of ambulatory patient experience in Nigeria teaching hospitals.

Methods: The study design is a cross-sectional exit survey. And the setting were outpatient departments of Nigerian Teaching Hospitals. Assessment of patient experiences for 5 domains of care, including waiting time, environment of the outpatient department, quality of doctor's care, quality of care by nurses/other health workers, responsiveness of care and the overall quality of care was carried out using structured questionnaire.

Results: The mean rating of quality of care or patient experience for the outpatients was $74.31 \pm 0.32 \%$. There were obvious but moderate differences among the hospitals for various levels of patients' care, especially for waiting time, quality of doctors' care and overall quality of care. Employment status was statistically significant $(p \leq 0.05)$ determinants of overall patient experience rating or quality of care for the outpatients, while the level of patient's education was an influence on the waiting time perception by the patients and their rating of care from nurses/other healthcare providers, other than doctors.

Conclusion: The study observed that socioeconomic factors such as educational and employment status of outpatients to some extent determines how outpatient perceived their experience while receiving healthcare in hospitals. Thus, there is need to institutionalize patient-centered care, giving full consideration to patients' socioeconomic status.

\section{Background}

People's state of health and the manner with which it is cared for is indeed regarded as a very important component of economic development of any country [1,2]. Health sector targets often relate to traditional hospital functions such as diagnosis, outpatient treatment and inpatient care. Outpatient services are those hospital services that do not require an overnight stay and can include things such as diagnostic tests, prescriptions or simple treatment/procedures [3]. This services is offered on ambulatory basis, and it account for majority of patient-medical professional encounters than any other hospital services (approximately four times than that of inpatients). Few studies have examined patient experience or quality of care in resource-scarce environment like sub-Saharan African countries such as Nigeria. The aim of this study is to evaluate patients' experience (PE) among clients accessing ambulatory healthcare services in teaching hospitals, Southeast Nigeria. Measurement of quality can be very useful to stakeholders who chooses between different health care providers, and to the policy makers who strive to enunciate better health policies [4]. Standardized surveys of patients and relatives can reliably measure hospital performance by assessing patients' experience and outcomes of treatment. Patient experience (PE) evaluates what happens at the point of contact between the patient, the practice, and the provider [5]. It does captures health system responsiveness, including the manner and environment in which people are treated when they seek healthcare [6]. It also include sufficient information and education of the patient, coordination of care, physical comfort, emotional support, respect for patient preferences, involvement of 
family and friends [4]. Patient experience is not the same as perceived quality which is predominantly a cognitive assessment of what happened and how it happened [7]. It is also different from patient satisfaction which is referred to as patients' emotion, feelings and their perception of delivered healthcare service [8]. Patient satisfaction is regarded as the degree of congruency between patient expectations of ideal care and their perception of the real care received [9] and it tend to ask patient to give subjective responses. In contrast, PE ask patients to give factual responses to questions about what did or did not happen during episode of care.

Threat to measuring healthcare quality in low and middle income countries (LMICs) was emphasized by a study carried out by Dunsch et al., (2017) on more than 2200 patients in Nigeria using positive and negative framed satisfaction statements [10]. The result show that patient satisfaction measurement are deeply sensitive to the framing of the questions and hence the need to adapt patient experience that avoids agree/disagree and yes/no questions. It is believed that PE survey questionnaires that are well designed and appropriately administered can provide robust measure of quality of care and reliably measure hospital performance against explicit standardization $[11,12]$. Several studies have been carried out on quality of healthcare services especially in developed countries, quite a handful in African region and very few in sub-Saharan African countries like Nigeria. Many reviewed literature on quality of healthcare show that waiting time is one of the most important indicators or variables of healthcare quality. One of such is a cross sectional observational study by the Patels (2017) on waiting time and outpatient satisfaction at Gujarat medical education research society hospital India, using 135patients from the outpatient department (OPD) [13]. A cross sectional survey of nurses $(33,659)$ and patients $(11,318)$ in 12 countries in Europe and the United States on patient safety, satisfaction and quality of hospital care, using hierarchical modelling and robust logistic regression, show that deficits in hospital care quality were common in all countries [14]. Mejabi et al., (2008) in their work on dimensions of hospital service quality in Nigeria, as published in European Journal of Social Sciences, used probability and quota sampling methods on 6 service points (medical outpatient clinic, surgical outpatient clinic, medical male ward, medical female ward, surgery male ward and surgery female ward) and applied correlation matrices/factor analysis to evaluate quality of healthcare in two Nigeria teaching hospitals. Their findings show that eight (8) dimensions of resource availability, quality of care, condition of the clinic/ward, condition of the facility, quality of food, attitude of doctors and nurses, attitude of non-medical staff and waiting time adequately describe service quality phenomena in Nigerian hospital setting [15]. No known studies in Nigeria have addressed the effect of socio-economic variables on patient experience (PE) as it concerns quality of hospital care. The present study focused on how socio-economic factors such as level of education and employment status of outpatients affect PE. These two socio-economic status (SES) were used because they were the commonest parameters used by the teaching hospitals in stratifying their patients.

\section{Methods}

The study design was cross-sectional exit survey. Three (3) hospitals were randomly selected from seven (7) teaching hospitals in Southeast, Nigeria. The study population was 7847 and that was projected outpatients flow for the 3 hospitals over a period of 3 months the data collection lasted. The sample size 
was thus determined using a formula for calculating required sample size for a patient population of less than 10000 persons. $N_{f}=n / 1+(n / N)$; $N$ is average number of target population. Value of $n$ was calculated using: $n=Z^{2} p q / d^{2}$ as the formula [16]. Where $n$ is minimum sample size required, $Z$ is normal standard deviation at $95 \%$ confidence level and is $1.96, p$ is prevalence of the factor under study (in this case the outpatients) and from previous studies it is $84 \%$ (0.84) for outpatients [17].

Structured patient experience questionnaire (PEQ) with scores assigned to the questions was developed and used for this study. The PEQ is designed to illicit actual experiences, ranging from the duration of hospital's waiting time to the environmental condition of the outpatient department, the quality of care rendered by the doctor and other health workers, the responsiveness of care and indeed the patient's overall rating of his experience. Reliability (internal and external consistency) of the PEQ was ensured using testretest reliability method and Cronbach's alpha test. The Cronbach's alpha coefficient was 0.632 . The questionnaire were anonymously administered (without patient's identifier) after a written consents were obtained [18]. A total of 408 outpatients accessing care in the 3 teaching hospitals participated in the study.

The data were analyzed using statistical methods such as Z-test and ANOVA to examine mean differences, and Chi-square/Log Linear association tools to compare the relationship between PE variables and socioeconomic factors.

\section{Results}

Gender distribution of the outpatients was $50.7 \%$ males and $49.3 \%$ females, and majority $(73 \%)$ of the patients were within active age range of $18-65$ years. About $24 \%$ were above $65 y$ years and $2.9 \%$ were below 18 years of age. $40.7 \%$ of the respondent had university education and $25.2 \%$ had high school education; the remaining $34.1 \%$ had either primary school education or no formal education. Less than half (about $41.7 \%$ ) were employed, while $28.2 \%$ were unemployed and $18.1 \%$ retirees that were no longer economically active. Table-1 also show that slight majority (51\%) of the patients were a cared for at the surgical outpatient department (SOPD), while $49 \%$ were cared for in medical outpatient department (MOPD).

\section{See Tables 1 and 2.}

Table-2 show significant statistical differences ( $\mathrm{p}$ 0.05) among hospitals for mean patient experience (PE) scores on waiting time, quality of doctors' care and that of overall rating. FETHA had the highest mean PE score for quality of doctor's care (43.89 \pm 7.04$)$ and for overall PE rating $(76.46 \pm 11.08 \%)$. While UNTH had the best score for waiting time PE score (11.32 \pm 5.73$)$.

\section{See Table 3.}

Table-3 disaggregates the healthcare services into medical and surgical, and compared the difference in their mean PE scores, within and between the hospitals. For instance, when the OPD environment is evaluated, FETHA's MOPD had mean PE score of $27.22 \pm 0.43$ points, thus better than its SOPD which had mean PE score of $25.36 \pm 0.52$ points. FETHA's MOPD overall PE rating was $78.37 \pm 1.14 \%$ and significantly 
higher than that of SOPD (74.85 \pm 1.29$)$. Similarly, in ESUTH the MOPD services were significantly $(\mathrm{p} \leq$ 0.05 ) better than those of SOPD for quality of doctor's care, quality of care by nurses/other health professionals, as well as for overall rating. Only UNTH's SOPD overall PE rating of $76.96 \pm 1.51 \%$ was significantly $(p \leq 0.05)$ better than that of its MOPD $(68.43 \pm 1.58 \%)$.

\section{See Table 4}

Table-4 show that higher proportion (61.1\%) of outpatients without a formal education had mean PE score of more than 10 points for waiting time, compared to $34.3 \%$ of outpatients with university education and $41.7 \%$ of those with high school education. The result show significant association between PE scores on waiting time and level of education. This was not so for PE score on OPD environment, quality of doctor's care and responsiveness of care for outpatients (as shown in table-4). With quality of care by nurses/other care givers, the result show significant $(p \leq 0.05)$ association with educational status; again larger proportion of outpatient without formal education (85.7\%) scored this domain high compared to $68.6 \%$ of outpatients with university education. The result also show that employment status only had significant $(\mathrm{p}$ $\leq 0.05$ ) association with the overall PE rating; about $75.7 \%$ of retirees and $64.7 \%$ of employed outpatients recorded higher overall PE rating in the hospitals studied. Students and un-employed had least overall PE rating.

\section{Discussion}

In the public eyes, hospitals will continue to be the 'face' of the health system, and upon it the public assess the quality of services provided [19]. There is an emerging consensus that the patient experience is a fundamental aspect of provider quality [20]. Measurement of patient experience is thus regarded as an important aspect of evaluation of health services; and it provides an opportunity to improve care, meet patients' expectations, enhance strategic decision making, effectively manage and monitor health care performance [21]. The present study evaluated how outpatients of two different socioeconomic group (educational and employment status) and it rate their experience in respect to various domain of care at the Teaching hospitals in Southeast Nigeria. The study is an attempt to know how Patient experience can serve as metric for health industry competition and differentiation, since it reflects quality of care from the patient's perspective [21]. The limitations of this study include its inability to capture all the domains of patient care in the hospitals. It was restricted to measures of outpatient or ambulatory healthcare services. Thus, the findings cannot be generalized to include that of admitted patients.

In this study 408 outpatients participated. The majority were within active age range of 18-65 years of age; $28.2 \%$ were unemployed and this is comparable to the prevailing unemployment rate in the general population of Nigeria as at the time of the study. Two-fifth (40\%) of the respondents had tertiary or university education, while very few $(13.2 \%)$ were without formal education. PE was measured using domains such as waiting time, environment of the OPDs, quality of doctor's care, quality of care from nurses/other medical staff and responsiveness of care. 
Waiting time, here, is defined as the length of time from when the patient enters the OPD to the time the patient actually leaves. And it is believed that reducing waiting time and making sure that patient receive the appropriate care timely will have a significant impact on quality of care [22]. UNTH had the shortest waiting time; patients spent less time waiting for services from doctor or other care giver. It is evident from previous studies that increased waiting time also affect the overall treatment provided by physician and other care givers [23]. In UK the national standard or accepted waiting time is 30 minutes [24]. In Nigeria, previous studies show that the majority of outpatients wait as long as 80-180 minutes or more in the OPDs, and the commonest reason for this long waiting time is the large number of patients as against few health workers $[17,25]$. A study in India obtained average waiting time outside the various OPDs of only 12 minutes and $98.52 \%$ of patients were very satisfied with it [13]. In the present work, the actual length of time were not ascertained. However, only a mere $44.4 \%$ of male patients and $39.3 \%$ of female patients were satisfied with the waiting time. The findings show that very educated patients, unlike the illiterate ones, are less satisfied with waiting time. Impact or effect of educational status was also noted for quality of care by the nurses/other health workers. Larger proportion of poorly educated outpatients rated this class of care higher. On the other hand, educational status was not significantly associated with patients' rating for OPD environment, doctors' care and responsiveness of care. This differs from the findings of Zalmanovitch and Vashdi (2014) who reported that a lower level of education predicates greater responsiveness of care for primary and preventive healthcare than higher level of educational status [26].

The mean overall patient experience rating in this study was $74.31 \pm 0.33 \%$. This score, though, higher than that of similar study in a Federal Medical Centre in Southeast Nigeria (where average satisfaction score of outpatients respondents was $66.8 \%$ ) is slightly below $83.0 \%$ obtained in a hospital of similar status (Aminu Kano teaching hospital) in Northern Nigeria $[27,28]$. The study showed that employment status, and not level of educational, had direct significant association with patients' rating for overall quality of care. Higher proportion of employed and retired outpatients rated the quality of care from the hospitals high. This, to some extent, is at variance with the findings of Arpey, et al (2017) who in their recent study observed that patients' SES had no impact in the way they are viewed or treated by their physicians [29]. However, our findings agreed with that of Myers, et al (2006) and Bernheim, et al (2008) who found that physicians as a group perceive and treat low SES patients differently from those of higher SES [30, 31]. Maharlouei, et al (2017) had also reported on how the overall patient experience was associated with different SES [32].

\section{Conclusion}

The study revealed how employment status was significantly associated with overall quality of care or patient experience rating for the hospitals. While level of education significantly impacted on how outpatients perceived waiting time and quality of care from nurses/other care givers in the hospital. Further study will be required to assess the impact of SES on inpatients' healthcare services of these hospitals.

\section{Recommendations}


The study has demonstrated the need to put into consideration the socioeconomic status of patients in the course of providing care for them.

\section{Declarations}

\section{Ethics approval and Consent to participate}

Permission for this study was obtained from Nigeria Federal Ministry of Health, and approvals were obtained from respective Health Research Ethical Committees of all the three participating Teaching hospital:

1. University of Nigeria Teaching Hospital Health Research Ethics Committee, NHREC/05/01/2008B-

FWA00002458-1 RB00002323;

2. Federal Teaching Hospital Health Research Ethics Committee, FETHA/REC/VOL1/2017/479; REC PROTOCOL NUMBER 14/02/2017 -24/02/2017;

3. Enugu State University Teaching Hospital Parklane, ESUTHP/C-MAC/RA/034/175.

Informed written consent were obtained from all patients that participated in the study. For those patients who were below 18years of age, parental written consent were obtained.

\section{Consent for publication}

Not applicable.

\section{Availability of data}

Data-sets used and analyzed for the study are available and may be released by the corresponding author on reasonable request.

\section{Competing interests}

The authors declare that they have no competing interests.

\section{Funding}

The data collection stage of the study was funded by the corresponding authors. The individual authors' time on the research design, data collection, analysis, interpretation and report writing were funded by each authors, respectively.

\section{Author's contributions}

HA conceptualized and designed the study and coordinated all the research activities including the drafting of the manuscript. OA coordinated the data collection. $\mathrm{OO}$ and $\mathrm{IO}$ contributed to the design of the study and oversaw the supervision the study. CN analyzed and interpreted the data. 
All authors reviewed the study findings, read and approved the manuscript before submission.

\section{Acknowledgment}

We are most grateful to the management and medical record departments of all the participating hospitals for their assistance.

\section{Abbreviations}

ESUTH: Enugu State University Teaching Hospital; FETHA: Federal University Teaching Hospital; LMICs: low and middle income countries; MOPD: medical outpatient department; OPD: outpatient department; PE: patient experience; PEQ: patient experience questionnaire; SES: socio-economic status; SOPD: surgical outpatient department; UNTH: University of Nigeria Teaching Hospital.

\section{References}

1. Eneji MA, Juliana, V.D, Onabe, B.J. Health care expenditure; health status and national productivity in Nigeria (1999-2012). Journal of Economics and International Finance. 2013; 5(7), 258-273.

2. Masoompour, M. S., Petramfar, P., Farhadi, P. and Mahdaviazad, H. Five-year trend analysis of capacity utilization measures in a teaching hospital 2008-2014. Shiraz E-Medical Journal. 2015; 16(2), ez1176.

3. Chansky, B., Garner, C. and Raichoudhary, R. Measuring output and productivity in private hospitals. US Bureau of Labour Statistics. 2013, October.

4. Jenkinson, C., Coulter, A. and Bruster, S.. The Picker Patient Experience Questionnaire: development and validation using data from in-patient surveys in five countries. International Journal for Quality in Health Care. 2002; 14(5), 353-358.

5. Wolf, J. A., Niederhauser, V., Marshburn, D. and LaVela, S.L. Defining patient experience. Patient Experience Journal. 2014; 1(1,3), 7-19.

6. Staniszewska, S., Boardman, F., Gunn, L., Roberts, J., Clay, D., Seers, K., Brett, J., Avital, L., Bullock, I. and O'Flynn, N. The Warwick patient experience franework: Patient-based evidence in clinical guideline. The International Journal for Quality in Health Care. 2014; 26(2), 151-7.

7. LaVela, S. L. and Gallan, A. S. Patient experience, evaluation and measurement of patient experience. Patient Experience Journal. 2014; 1(1, 5), 28-56.

8. Rama, M. and Kanagaluru, S. K. A study on the satisfaction of patients with referrence to hospital services. Intl Journal of Business Economics \& Mgt Research. 2011; 1(3), 15-25.

9. Iftikhar, A., Allah, N., Shaduiullah, K., Habibullah, K., Muhammad, A. R. and Muhammad, H. K. Predictor of patient satisfaction. Gomal Journal of Medical Science. 2011; 9(2), 183-1888.

10. Dunsch F., Evans D., K., Macis M., and Wang Q. Bias in patient satisfaction surveys: a threat to measuring healthcare quality. BMJ Glob Health. 2018; 3(2): e000694. doi: 10.1136/bmjgh-2017000694. 
11. Manary, M. P., Boulding, W., Staelin, R. and Glickman, S. W. (2013). The patient experience and health outcomes. New England Journal of Medicine, 368, 201-203.

12. Ashton, F., Hamid, K., Sulieman, S., Eardley, W. and Baker, P. (2017). Factors influencing patient experience and satisfaction following surgical management of ankle fractures. Injury Journal, 48(4), 960-965.

13. Patel, R. and Patel, H. R. A study on waiting time and out-patient satisfaction at Gujarat medical education research society hospital, Valsad, Gujarat, India. International Journal of Community Medicine and Public Health. 2017; 4(3), 857-863.

14. Aiken L. H., Sermeus W., Heede K.V., Sloane d. M., Busse R., McKee M., Bruynee L., Rafferty A. M., Griffiths P., Moreno-Casbas M. T., Tishelman C., Scott A., Brzostek T., Kinnunen J., Schwendimann R., Heinen M., Zikos D., Sjetne I. S., Smith H. L., Kutney-Lee A.(2012). Patient safety, satisfaction, and quality of hospital care: cross sectional surveys of nurses and patients in 12 countries in Europe and the United States. BMJ 2012;344:e1717, doi: https://doi.org/10.1136/bmj.e1717.

15. Mejabi, O. V. and Olujide, J. O. (2008). Dimensions of hospital service quality in Nigeria. European Journal of Social Sciences, 5(4), 141-159.

16. Ofilli, A. N. and Ofowve, C. E. (2005). Patient's assessment of efficiency of services at a teaching hospital in a developing country. Annals African Medical, 4, 150-153

17. Oche, M. O. and Adamu, H. Determinants of patient waiting time in the general outpatient department of a tertiary health institution in the North Western Nigeria. Annals of Medical and Health Science Research. 2013; 3(4), 588-592.

18. Garrat, A. M., Bjaertnes, A., Krogstad, U. and Gulbrandsen, P. The Outpatient Experience Questionnaire (OPEQ): Data quality, reliability and validity in patients attending 52 Norwegian hospitals. BMJ Journals.2016; 13, 433-437.

19. Mujasi, P. N., Asbu, E. Z. and Puig-Junoy, J. How efficient are referral hospitals in Uganda? A data envelopment analysis and Tobit regression approach. BMC Health Services Research. 2016; 8(16), 230.

20. Doyle, C., Lennox, L. and Bell, D. (2013). A systematic review of evidence on the links between patient experience and clinical safety and effectiveness. British Medical Journal Open, 3(1), 1-18.

21. Wong, E. L. Y., Coulter, A., Hewitson, P., Cheung, A. W. L., Yam, C. H. K., Lui, S., Tam, W. S. and Yeoh, E. (2015). Patient experience and satisfaction with inpatient aservices: Development of short form survey instrument measuring the core aspect of inpatient experience. PLOS ONE, 10(4), 1-12.

22. Pandit, A., Varma, L. and Amruta, P. Impact of OPD waiting time on patient satisfaction. International Education \& Research Journal. 2016; 2(8), 86-90.

23. Bleustein, C., Rothschild, D. B., Valen, A., Valatis, E., Schweitzer, L. and Jones, R. (2014). Wait time, patient satisfaction, and the perception of care. American Journal of Manag Care, 20(5), 393-400. 
24. Yeboah, E. and Thomas, M. A cost effective way of reducing outpatient clinic waiting times: How we did it. The Internet Journal of Healthcare Administration. 2009; 7(1).

25. Ameh, N., Sabo, B., and Oyefabi, M.O. Application of queuing theory to patient satisfaction at a tertiary hospital in Nigeria. Nigerian Medical Journal. 2013; 54, 64-7.

26. Zalmanovitch, Y. and Vashdi, D. R. (2014). The relationship between socioeconomic factors and responsiveness gaps in primary, preventive and health promotion services. Health Expectations: An International Journal of Public Participation in Healthcare and Health Policy. https:doi.org/10.1111/hex.12238. Retrieved on 22 ${ }^{\text {nd }}$ October, 2018.

27. Iloh, G. U. P., Ofoedu, J. N., Njoku, P. U., Odu, F.U., Ifedigbo, C. V. and Iwuamanam, K. D. Evaluation of patients' satisfaction with quality of care provided at the National Health Insurance Scheme clinic of a tertiary hospital in South-Eastern Nigeria. Nigerian Journal of Clinical Practice. 2012; 15(4), 469-474.

28. Iliyasu, Z., Abubakar, I. S., Lawan, U. M. and Gajida, A. U. (2010). Patients' satisfaction with services obtained from Aminu Kano Teaching Hospital, Northern Nigeria. Nigerian Journal Clinical Practice, 13(4), 371-378

29. Arpey, N. C., Gaglioti, A. H., Rosenbau, M. E. How Socioeconomic Status affects patient's perceptions of Healthcare: A qualitative study. Journal of Primary Care \& community Health; 2017. https:org/10.1177/2150131917697439. Retrieved 20 ${ }^{\text {th }}$ October, 2018.

30. Meyers, D. S., Mishori, R., McCann, J. Primary care physicians' perceptions of the effect of insurance status on clinical decision making. Annual of Family Medicine. 2006; Vol. 4, No. 2 399-402.

31. Bernheim, S. M., Ross, J. S., Krumbolz, H. M., Bradley, E. H. (2008). Influence of patients' socioeconomic status on clinical management decisions: A Qualitative Study. Annals of Family Medicine. Vil. 6, No. 1: 53 -59.

\section{Tables}

Table-1: Demography and socioeconomic status of the outpatients 


\begin{tabular}{|c|c|c|c|c|c|c|c|}
\hline \multirow{2}{*}{ Variable } & \multirow{2}{*}{ Categories } & \multicolumn{6}{|c|}{ Hospital } \\
\hline & & \multicolumn{2}{|c|}{ FETHA } & \multicolumn{2}{|c|}{ ESUTH } & UNTH & Total \\
\hline \multirow[t]{2}{*}{ Sex } & Male & \multicolumn{2}{|c|}{$87(55.1)$} & \multicolumn{2}{|c|}{$67(49.3)$} & $53(46.5)$ & $207(50.7)$ \\
\hline & Female & \multicolumn{2}{|c|}{$71(44.9)$} & \multicolumn{2}{|c|}{$69(50.7)$} & $61(53.5)$ & $201(49.3)$ \\
\hline \multirow[t]{3}{*}{ Marital Status } & Married & \multicolumn{2}{|c|}{$110(69.6)$} & \multicolumn{2}{|c|}{$98(72.1)$} & $71(62.3)$ & $279(68.4)$ \\
\hline & Not Married & \multicolumn{2}{|c|}{$41(25.9)$} & \multicolumn{2}{|c|}{$32(23.5)$} & $40(35.1)$ & $113(27.7)$ \\
\hline & Others & \multicolumn{2}{|c|}{$7(4.4)$} & \multicolumn{2}{|c|}{$6(4.4)$} & $3(2.6)$ & 16(3.9) \\
\hline \multirow[t]{3}{*}{ Age(Years) } & $<=18$ & \multicolumn{2}{|c|}{$6(3.8)$} & \multicolumn{2}{|c|}{$2(1.5)$} & $4(3.5)$ & $12(2.9)$ \\
\hline & $19-64$ & \multicolumn{2}{|c|}{$112(70.9)$} & \multicolumn{2}{|c|}{$96(70.6)$} & $90(78.9)$ & $298(73)$ \\
\hline & $65+$ & \multicolumn{2}{|c|}{$40(25.3)$} & \multicolumn{2}{|c|}{$38(27.9)$} & $20(17.5)$ & $98(24)$ \\
\hline \multirow{5}{*}{$\begin{array}{c}\text { SES } \\
\text { Level of Education }\end{array}$} & & & & & & & \\
\hline & \multicolumn{2}{|c|}{ No Formal Education } & \multicolumn{2}{|c|}{$23(14.6)$} & $15(11)$ & $16(14)$ & $54(13.2)$ \\
\hline & \multicolumn{2}{|c|}{ Primary Education } & \multicolumn{2}{|c|}{$36(22.8)$} & $26(19.1)$ & $23(20.2)$ & $85(20.8)$ \\
\hline & \multicolumn{2}{|c|}{ Secondary Education } & \multicolumn{2}{|c|}{$50(31.6)$} & $29(21.3)$ & $24(21.1)$ & $103(25.2)$ \\
\hline & \multicolumn{2}{|c|}{ University Education } & \multicolumn{2}{|c|}{$49(31)$} & $66(48.5)$ & $51(44.7)$ & $166(40.7)$ \\
\hline \multirow[t]{4}{*}{ Employment Status } & \multicolumn{2}{|c|}{ Employed } & \multicolumn{2}{|c|}{$68(43)$} & $56(41.2)$ & $46(40.4)$ & $170(41.7)$ \\
\hline & Not Employed & & 37( & & $34(25)$ & $44(38.6)$ & $115(28.2)$ \\
\hline & Student & & 22( & & $13(9.6)$ & $14(12.3)$ & $49(12)$ \\
\hline & $\begin{array}{l}\text { Retired } \\
\text { otal }\end{array}$ & & $\begin{array}{l}31( \\
158 \\
\end{array}$ & & $\begin{array}{l}33(24.3) \\
136(100)\end{array}$ & $\begin{array}{c}10(8.8) \\
114(100)\end{array}$ & $\begin{array}{r}74(18.1) \\
408(100)\end{array}$ \\
\hline
\end{tabular}

The figures in the bracket, (), are \% along the column.

Indicates a significant different $(p<0.05)$, while the $p$-value of less than 0.05 indicates a significant difference between the hospital services (medical and surgical)

Table-2: Analysis of Mean Difference for Patient's Experience Variables

\begin{tabular}{|c|c|c|c|c|c|}
\hline \multirow[t]{2}{*}{ Variable } & \multicolumn{5}{|c|}{ Hospital } \\
\hline & FETHA & ESUTH & UNTH & $\begin{array}{c}\text { p- } \\
\text { value }\end{array}$ & Remark \\
\hline Waiting Time & $10.56^{\mathrm{b}} \pm 4.96$ & $7.67^{\mathrm{a}} \pm 4.23$ & $11.32^{\mathrm{b}} \pm 5.73$ & 0.000 & Significant \\
\hline OPD Environment & $26.21^{\mathrm{a}} \pm 4.42$ & $26.64^{\mathrm{a}} \pm 4.95$ & $27.09^{\mathrm{a}} \pm 4.10$ & 0.285 & $\begin{array}{l}\text { Not } \\
\text { Significant }\end{array}$ \\
\hline Quality of Doctors Services & $43.89^{\mathrm{C}} \pm 7.04$ & $41.63^{\mathrm{b}} \pm 9.23$ & $38.66^{\mathrm{a}} \pm 9.74$ & 0.000 & Significant \\
\hline $\begin{array}{l}\text { Quality of care by Nurses/Other } \\
\text { Medical Staff }\end{array}$ & $22.04^{\mathrm{a}} \pm 7.23$ & $19.89^{\mathrm{a}} \pm 6.60$ & $19.95^{\mathrm{a}} \pm 7.67$ & 0.172 & $\begin{array}{l}\text { Not } \\
\text { Significant }\end{array}$ \\
\hline Responsiveness & $48.83^{a} \pm 13.38$ & $51.07^{\mathrm{a}} \pm 10.86$ & $48.82^{\mathrm{a}} \pm 15.93$ & 0.282 & $\begin{array}{l}\text { Not } \\
\text { Significant }\end{array}$ \\
\hline Overall Quality Rating (\%) & $76.46^{\mathrm{b}} \pm 11.08$ & $72.90^{\mathrm{a}} \pm 11.89$ & $73.00^{\mathrm{a}} \pm 12.39$ & 0.014 & Significant \\
\hline
\end{tabular}

Values are mean \pm Standard Deviation. Mean values along the row with different alphabetical superscript indicates a significant different. 
Table-3: Analysis of mean difference for Patient's Experience variables scores among patients, along type of care (Surgical and Medical)

\begin{tabular}{|c|c|c|c|c|c|c|c|}
\hline \multirow[t]{2}{*}{ Variable } & \multirow{2}{*}{$\begin{array}{l}\text { Service } \\
\text { Type }\end{array}$} & \multicolumn{3}{|c|}{ Hospital } & \multirow[b]{2}{*}{$\begin{array}{c}\mathrm{P}- \\
\text { value }\end{array}$} & \multirow[b]{2}{*}{ Remark } & \multirow[b]{2}{*}{ OVERALL } \\
\hline & & FETHA & ESUTH & UNTH & & & \\
\hline \multirow[t]{3}{*}{ Waiting Time } & Medical & $11.0^{\mathrm{b}} \pm 0.53$ & $7.4^{\mathrm{a}} \pm 0.47$ & $11.67^{\mathrm{a}} \pm 0.91$ & 0.000 & Significant & $9.75^{\mathrm{a}} \pm 0.38$ \\
\hline & Surgical & $10.18^{\mathrm{b}} \pm 0.58$ & $8.0^{\mathrm{a}} \pm 0.56$ & $11.31^{\mathrm{b}} \pm 0.62$ & 0.001 & Significant & $9.88^{\mathrm{a}} \pm 0.35$ \\
\hline & $\mathrm{p}$-value & 0.290 & 0.417 & 0.749 & & & 0.801 \\
\hline \multirow{4}{*}{$\begin{array}{l}\text { OPD } \\
\text { Environment }\end{array}$} & Medical & $27.22^{\mathrm{a}} \pm 0.43$ & $26.44^{\mathrm{a}} \pm 0.52$ & $25.85^{\mathrm{a}} \pm 0.55$ & 0.170 & Insignificant & $26.57^{\mathrm{a}} \pm 0.29$ \\
\hline & Surgical & $25.36^{\mathrm{a}} \pm 0.52$ & $26.89^{\mathrm{b}} \pm 0.70$ & 28.16 & 0.002 & Significant & $26.63^{\mathrm{a}} \pm 0.34$ \\
\hline & & & & $\mathrm{b}_{ \pm 0.498}$ & & & \\
\hline & $\mathrm{p}$-value & $0.007 *$ & 0.611 & $0.002 *$ & & & 0.885 \\
\hline \multirow{3}{*}{$\begin{array}{l}\text { Quality of } \\
\text { Doctors' care } \\
\text { or Services }\end{array}$} & Medical & $44.63^{\mathrm{b}} \pm 0.68$ & $43.75^{\mathrm{b}} \pm 0.86$ & $35.25^{\mathrm{a}} \pm 1.60$ & 0.000 & Significant & $41.8^{\mathrm{a}} \pm 0.57$ \\
\hline & Surgical & $43.27^{\mathrm{a}} \pm 0.85$ & $39.03^{\mathrm{a}} \pm 1.34$ & $41.62^{\mathrm{a}} \pm 1.90$ & 0.028 & Significant & $41.54^{\mathrm{a}} \pm 0.66$ \\
\hline & $p$-value & 0.216 & $0.004^{*}$ & $0.026 *$ & & & 0.761 \\
\hline \multirow{3}{*}{$\begin{array}{l}\text { Quality of care } \\
\text { or Services by } \\
\text { Other Medical } \\
\text { Staff }\end{array}$} & Medical & $22.71^{\mathrm{a}} \pm 1.17$ & $22.4^{\mathrm{a}} \pm 1.13$ & $19.23^{\mathrm{a}} \pm 1.63$ & 0.142 & Insignificant & $21.62^{\mathrm{a}} \pm 0.78$ \\
\hline & Surgical & $21.64^{\mathrm{b}} \pm 1.01$ & $16.47^{\mathrm{a}} \pm 1.81$ & $20.88^{\mathrm{b}} \pm 1.90$ & 0.065 & Insignificant & $20.60^{\mathrm{a}} \pm 0.82$ \\
\hline & $\mathrm{p}$-value & 0.49 & $0.010 *$ & 0.513 & & & 0.371 \\
\hline \multirow{4}{*}{ Responsiveness } & Medical & $50.00^{\mathrm{b}}$ & $50.53^{\mathrm{b}} \pm 1.40$ & $42.92^{\mathrm{a}} \pm 2.38$ & 0.003 & Significant & $48.33^{\mathrm{a}} \pm 0.97$ \\
\hline & & \pm 1.29 & & & & & \\
\hline & Surgical & $47.85^{\mathrm{a}} \pm 1.63$ & $51.72^{\mathrm{b}} \pm 1.17$ & $53.93^{\mathrm{b}} \pm 1.62$ & 0.016 & Significant & $50.77^{\mathrm{a}} \pm 0.91$ \\
\hline & p-value & 0.302 & 0.515 & $0.000 *$ & & & 0.066 \\
\hline \multirow{3}{*}{$\begin{array}{l}\text { Overall Rating } \\
\text { (in \%) }\end{array}$} & Medical & $78.37^{\mathrm{c}} \pm 1.14$ & $74.53^{\mathrm{b}} \pm 1.22$ & $68.43^{\mathrm{a}} \pm 1.58$ & 0.000 & Significant & $74.30^{\mathrm{a}} \pm 0.79$ \\
\hline & Surgical & $74.85^{\mathrm{b}} \pm 1.29$ & $70.89^{\mathrm{a}} \pm 1.68$ & $76.96^{\mathrm{b}} \pm 1.51$ & 0.020 & Significant & $74.31^{\mathrm{a}} \pm 0.86$ \\
\hline & p-value & $0.043 *$ & $0.041 *$ & $0.000 *$ & & & 0.993 \\
\hline
\end{tabular}

Values are mean \pm Standard Deviation. Mean values along the row (among the hospitals) with different alphabetical superscript indicates a significant different $(p<0.05)$, while the $p$-value of less than 0.05 indicates a significant difference between the hospital services (medical and surgical)

Table-4: Measure of association between Patient Experience variables and socioeconomic status of outpatients 


\begin{tabular}{|c|c|c|c|c|c|}
\hline \multirow[t]{2}{*}{ SES } & \multirow[t]{2}{*}{ Categories } & \multicolumn{2}{|c|}{ Waiting Time } & \multirow[t]{2}{*}{ Chi-Square } & \multirow{2}{*}{$\begin{array}{l}\text { Linear by Linear } \\
\text { Association }\end{array}$} \\
\hline & & $\leq 10$ & $>10$ & & \\
\hline \multirow{5}{*}{$\begin{array}{l}\text { Level of } \\
\text { Education }\end{array}$} & No Formal & $21^{\mathrm{a}}(38.9)$ & $33^{\mathrm{a}}(61.1)$ & & $11.215[0.001]^{*}$ \\
\hline & Primary & $47^{b}\left(55_{3}\right)$ & $38^{\mathrm{b}}(447)$ & & \\
\hline & Education & It (U.) & (Ix. & & \\
\hline & Secondary & $60^{c}(58.3)$ & $43^{\mathrm{C}}(41.7)$ & & \\
\hline & $\begin{array}{l}\text { Tertiary } \\
\text { Education }\end{array}$ & $109^{\mathrm{d}}(65.7)$ & $57^{\mathrm{d}}(34.3)$ & & \\
\hline \multirow{4}{*}{$\begin{array}{l}\text { Employment } \\
\text { Status }\end{array}$} & Employed & $102^{\mathrm{a}}(60)$ & $68^{\mathrm{a}}(40)$ & $6.358[0.95]$ & \\
\hline & Not Employed & $56^{c}(48.7)$ & $59^{c}(51.3)$ & & \\
\hline & Student & $31^{\mathrm{a}}(63.3)$ & $18^{a}(36.7)$ & & \\
\hline & Retired & $48^{\mathrm{b}}(64.9)$ & $26^{b}(35.1)$ & & \\
\hline Variable & Categories & \multicolumn{2}{|c|}{$\leq 15 \stackrel{\text { OPD Environment }}{>15}$} & Chi-Square & Linear by Linear \\
\hline \multirow{5}{*}{$\begin{array}{l}\text { Level of } \\
\text { Education }\end{array}$} & No Formal & $\leq 10$ & & & Association \\
\hline & Education & $1^{a}(1.9)$ & $53^{\mathrm{d}}(98.1)$ & & $2.33 /[0.120]$ \\
\hline & $\begin{array}{l}\text { Primary } \\
\text { Education }\end{array}$ & $4^{\mathrm{a}}(4.7)$ & $81^{\mathrm{a}}(95.3)$ & & \\
\hline & $\begin{array}{l}\text { Secondary } \\
\text { Education }\end{array}$ & $5^{\mathrm{a}}(4.9)$ & $98^{\mathrm{a}}(95.1)$ & & \\
\hline & $\begin{array}{l}\text { Tertiary } \\
\text { Education }\end{array}$ & $12^{\mathrm{a}}(7.2)$ & $154^{\mathrm{a}}(92.8)$ & & \\
\hline \multirow{4}{*}{$\begin{array}{c}\text { Employment } \\
\text { Status }\end{array}$} & Employed & $14^{\mathrm{a}}(8.2)$ & $156^{\mathrm{a}}(91.8)$ & $4.734[0.192]$ & \\
\hline & Not Employed & $4^{\mathrm{a}}(3.5)$ & $111^{\mathrm{a}}(96.5)$ & & \\
\hline & Student & $2^{\mathrm{a}}(4.1)$ & $47^{a}(95.9)$ & & \\
\hline & Retired & $2^{\mathrm{a}}(2.7)$ & $72^{\mathrm{a}}(97.3)$ & & \\
\hline Variable & Categories & \multicolumn{2}{|c|}{ Quality of Doctors Services } & Chi-Square & Linear by Linear \\
\hline \multirow{5}{*}{$\begin{array}{l}\text { Level of } \\
\text { Education }\end{array}$} & No Formal & $5^{a}(9.3)$ & $49^{\mathrm{a}}(90,7)$ & & $0.246[0.62]$ \\
\hline & Education & & & & \\
\hline & $\begin{array}{l}\text { Primary } \\
\text { Education }\end{array}$ & $8^{\mathrm{a}}(9.4)$ & $77^{\mathrm{a}}(90.6)$ & & \\
\hline & $\begin{array}{l}\text { Secondary } \\
\text { Education }\end{array}$ & $6^{\mathrm{a}}(5.8)$ & $97^{\mathrm{a}}(94.2)$ & & \\
\hline & Tertiary & $13^{\mathrm{a}}(7.8)$ & $153^{\mathrm{a}}(92.2)$ & & \\
\hline \multirow{4}{*}{$\begin{array}{l}\text { Employment } \\
\text { Status }\end{array}$} & Employed & $13^{b}(7.6)$ & $157^{\mathrm{b}}(92.4)$ & $6.706[0.082]$ & \\
\hline & Not Employed & $12^{\mathrm{C}}(10.4)$ & $103^{\mathrm{C}}(89.6)$ & & \\
\hline & Student & $6^{\mathrm{C}}(12.2)$ & $43^{C}(87.8)$ & & \\
\hline & Retired & $1^{\mathrm{a}}(1.4)$ & $73^{a}(98.6)$ & & \\
\hline Variable & Categories & \multicolumn{2}{|c|}{$\begin{array}{l}\text { Quality of care or Services by } \\
\text { Nurses/other Medical Staff }\end{array}$} & Chi-Square & $\begin{array}{l}\text { Linear by Linear } \\
\text { Association }\end{array}$ \\
\hline & & $\leq 25$ & $>25$ & & \\
\hline \multirow{4}{*}{$\begin{array}{l}\text { Level of } \\
\text { Education }\end{array}$} & No Formal & $3^{\mathrm{a}}(14.3)$ & $18^{\mathrm{c}}(85.7)$ & & $7.132[0.008]^{*}$ \\
\hline & Primary & $5^{b}(20.8)$ & $19^{\mathrm{b}}(79.2)$ & & \\
\hline & $\begin{array}{l}\text { Education } \\
\text { Secondary }\end{array}$ & $10^{\mathrm{b}}(19.6)$ & $41^{\mathrm{b}}(80.4)$ & & \\
\hline & $\begin{array}{l}\text { Education } \\
\text { Tertiary } \\
\text { Education }\end{array}$ & $26^{\mathrm{C}}(38.2)$ & $41^{\mathrm{a}}(60.3)$ & & \\
\hline Employment & Employed & $13^{\mathrm{a}}(20.3)$ & $51^{\mathrm{a}}(79.7)$ & $5.057[0.536]$ & \\
\hline
\end{tabular}


Each superscript letter denotes a subset of Variable categories whose row proportions do not differ significantly from each other at the .05 level, ( )-\%, [ ] - p-value.

Table-4 Cont. Measure of association of Patient Experience Variables and Socio-economic status of outpatients

\begin{tabular}{|c|c|c|c|c|c|}
\hline \multirow[t]{2}{*}{ SES } & \multirow[t]{2}{*}{ Categories } & \multicolumn{2}{|c|}{ Responsiveness } & \multirow[t]{2}{*}{ Chi-Square } & \multirow{2}{*}{$\begin{array}{l}\text { Linear by } \\
\text { Linear } \\
\text { Association }\end{array}$} \\
\hline & & $\leq 50$ & $>50$ & & \\
\hline \multirow{4}{*}{$\begin{array}{c}\text { Level of } \\
\text { Education }\end{array}$} & \multirow{2}{*}{$\begin{array}{l}\text { No Formal } \\
\text { Education } \\
\text { Primary Education }\end{array}$} & $18^{\mathrm{a}}(33.3)$ & $36^{\mathrm{a}}(66.7)$ & \multirow{8}{*}{$0.675[0.879]$} & \multirow[t]{8}{*}{$0.569[0.451]$} \\
\hline & & $33^{\mathrm{a}}(38.8)$ & $52^{\mathrm{a}}(61.2)$ & & \\
\hline & $\begin{array}{l}\text { Secondary } \\
\text { Education }\end{array}$ & $37^{\mathrm{a}}(35.9)$ & $66^{\mathrm{a}}(64.1)$ & & \\
\hline & Tertiary Education & $52^{\mathrm{a}}(31.3)$ & $114^{\mathrm{a}}(68.7)$ & & \\
\hline \multirow{4}{*}{$\begin{array}{l}\text { Employment } \\
\text { Status }\end{array}$} & Employed & $55^{\mathrm{a}}(32.4)$ & $115^{\mathrm{a}}(67.6)$ & & \\
\hline & Not Employed & $42^{\mathrm{a}}(36.5)$ & $73^{a}(63.5)$ & & \\
\hline & Student & $18^{\mathrm{a}}(36.7)$ & $31^{\mathrm{a}}(63.3)$ & & \\
\hline & Retired & $25^{\mathrm{a}}(33.8)$ & $49^{\mathrm{a}}(66.2)$ & & \\
\hline \multirow[t]{2}{*}{ Variable } & \multirow[t]{2}{*}{ Categories } & \multicolumn{2}{|c|}{ Overall Rating (\%) } & \multirow[t]{2}{*}{ Chi-Square } & \multirow{6}{*}{$\begin{array}{c}\text { Linear by } \\
\text { Linear } \\
\text { Association } \\
1.312[0.252]\end{array}$} \\
\hline & & $\leq 70$ & $>70$ & & \\
\hline \multirow[t]{4}{*}{$\begin{array}{l}\text { Level of } \\
\text { Education }\end{array}$} & $\begin{array}{l}\text { No Formal } \\
\text { Education }\end{array}$ & $17^{\mathrm{a}}(31.5)$ & $37^{\mathrm{a}}(68.5)$ & \multirow{8}{*}{$8.711[0.033]^{*}$} & \\
\hline & $\begin{array}{l}\text { Primary } \\
\text { Education }\end{array}$ & $32^{\mathrm{a}}(37.6)$ & $53^{\mathrm{a}}(62.4)$ & & \\
\hline & $\begin{array}{l}\text { Secondary } \\
\text { Education }\end{array}$ & $33^{a}(32)$ & $70^{a}(68)$ & & \\
\hline & $\begin{array}{l}\text { Tertiary } \\
\text { Education }\end{array}$ & $68^{\mathrm{a}}(41)$ & $98^{a}(59)$ & & \\
\hline \multirow{4}{*}{$\begin{array}{l}\text { Employment } \\
\text { Status }\end{array}$} & Employed & $60^{\mathrm{b}}(35.3)$ & $110^{\mathrm{b}}(64.7)$ & & \\
\hline & Not Employed & $51^{\mathrm{C}}(44.3)$ & $64^{\mathrm{C}}(55.7)$ & & \\
\hline & Student & $21^{\mathrm{c}}(42.9)$ & $28^{\mathrm{C}}(57.1)$ & & \\
\hline & Retired & $18^{\mathrm{a}}(24.3)$ & $56^{\mathrm{a}}(75.7)$ & & \\
\hline
\end{tabular}

Each superscript letter denotes a subset of Variable categories whose row proportions do not differ significantly from each other at the .05 level, ( )-\%, [ ] - p-value.

\section{Supplementary Files}

This is a list of supplementary files associated with this preprint. Click to download.

- Additionalfile3.docx

- AdditionalFile1.PatientExperienceQuestionairePEQ.docx

- Additionalfile2.docx 